\title{
Subtle Varieties of Love within Cecil B. DeMille's Samson and Delilah (1949)
}

\author{
By Anton Karl Kozlovic
}

Fall 2008 Issue of KINEMA

\section{EXPLORING THE SUBTLE VARIETIES OF LOVE WITHIN CECIL B. DeMILLE'S SAM- SON AND DELILAH (1949)}

\section{Introduction: Cecil's Samson Saga}

Producer-director $^{(1)}$ Cecil B. DeMille ${ }^{(2)}$ (1881-1959), affectionately known as CB, was a co-founder of Hollywood, a progenitor of Paramount studio and an unsung auteur who helped turn an obscure Californian orange grove into a major movie centre that became the synonym for commercial filmmaking worldwide. ${ }^{(3)}$ Not only did DeMille help institute "the Age of Hollywood" (Paglia 1994, 12), but this pioneering "auteur of auteurs" (Vidal 1995, 303) became the master of the American biblical epic with such indelible classics as The Ten Commandments (silent), The King of Kings, Samson and Delilah and The Ten Commandments (sound). Not surprisingly, he was subsequently tagged "King of the epic Biblical spectacular" (Finler 1985, 32), the "high priest of the religious genre" (Holloway 1977, 26) and the "arch apostle of spectacle" (Clapham 1974, 21) amongst many other honours, titles and awards (see Essoe and Lee 1970, 245-247).

As Hollywood's leading cinematic lay preacher who utilised the silver screen as his sermonising tool, DeMille deserved these critical and industry accolades. Indeed, his page-to-projector adaptation of the Samson saga starring Victor Mature as Samson, Hedy Lamarr as Delilah, and based upon Judges 13-16 ${ }^{(4)}$ was a "watershed film" (Schatz 1997, 394) that triggered the 1950-60s rash of Hollywood biblical epics. Nowadays, "televised DeMille is essentially the Bible for the TV generation" (Brode 1995, 68) whilst Samson and Delilah's reputation has "stabilised into one of camp respectability" (Murphy 1999, 109-110) and is increasingly admired by professional biblical scholars as a significant cine-text that changed popular perceptions of sacred Scripture, their exegetical profession and contemporary Western culture. For example, J. Cheryl Exum (1996) enthusiastically proclaimed that it:

...offers a good example of cinematic impact on the culture at large. It is not a little-known film; I have seen it at least four times on television in the UK in the past three years. With the kind of promotion television offers, De Mille's Oscar-winning epic has certainly reached more audiences than when it was first released, and through repeated television showings it continues to be influential in forming people's opinions about the biblical story. For all its hokeyness Samson and Delilah is a brilliant film (13).

Exum's scholarly peer David Jasper (1999) likewise claimed:

In the Hollywood tradition of Old Testament epics...the cinema has occasionally contributed in a significant way to the history of biblical interpretations, perhaps unwittingly and most notably in the figure of Cecil B. De Mille in films like Samson and Delilah (1949) and The Ten Commandments (1956)...[DeMille] re-reads the text of the Book of Judges midraschically as a love story which shifts the coherent and dehumanizing biblical perspective of Israel's salvation history and replaces it with a countercoherence of a Delilah following her heart and remaining true to Samson... (51).

Indeed, Jasper (1999) considered DeMille's romantic repackaging of sacred Scripture to be a service to mainstream biblical scholarship. As he claimed:

...De Mille's film [Samson and Delilah] does what art and literature has always in fact done, read the Bible and unpicked its historical and theological consistencies which have defined how religious orthodoxy has read it, and offered a countercoherence in terms of other priorities (in this case filmic melodrama) which may expose the dangerous assumptions that often underlie our reading of Scripture and the Bible... (51-52). 
In essence, DeMille-the-self-confessed-pop-culture-professional (DeMille and Hayne 1960, 195) had engaged in what today's theologians call a hermeneutic of creative imagination in his cinematic attempt to interpret the Bible and present it for mass consumption. As Elisabeth Schussler Fiorenza (2001) described this artistic process:

A hermeneutic of imagination retells biblical stories, re-shapes religious vision, and celebrates those who have brought about change. To that end it does more than utilize historical, literary, and ideological-critical methods, which focus on the rhetoric of religious texts and their historical contexts. It also employs methods of storytelling, role-playing, bibliodrama, Midrash, pictorial arts, dance, meditation, prayer, and ritual for creating a "different" religious imagination... (181).

Only DeMille-the-Hollywood-storyteller created his different religious imagination using commercial feature films as his creative palette. In that auteuristic process, DeMille had set the standard for the American biblical epic, shaped the next generation of offerings in that holy genre, and established filmmaking precedents that other directors desperately tried to imitate, subvert or appropriate in their attempts to duplicate his box office success. As movie mogul Darryl F. Zanuck enviously claimed regarding Samson and Delilah, it "is basically a sex story and when you get one in biblical garb apparently you can open your own mint" (Gussow 1971, 81).

\section{DeMille: The Unappreciated and Derided Filmmaker}

Regrettably, the breadth, depth and inventiveness of DeMille's artistic prowess has not been fully appreciated to date, although this is slowly being corrected as recently indicated by director George Cukor who belatedly confessed:

A long time ago I thought what he [DeMille] did was a big joke, just preposterous, and I couldn't understand why the audience went for it in such a big way. There were always all sorts of orgies with belly dancers, veils and all the trappings. The eroticism was a joke. Then I saw The Ten Commandments [1956]...it was preposterous from the word go but I suddenly saw something new there, something which had escaped me before: the story telling was wonderful. The way that man could tell a story was fascinating - you were riveted to your seat. That's exactly what he was: a great, great story teller. It was often ridiculous with all those excesses and froth but the man did tell a story. That was De Mille's great talent and the secret behind his popular success (Long 2001, 27).

One of the many trade secrets behind DeMille's great story-telling prowess that underpinned his creative brilliance and helped establish his trademark auteur signature was his engineering of subtle variation upon a particularly theme, topic or issue. This artistic practice was usually done discreetly by DeMille and was frequently overlooked by his decrying critics. However, DeMille was forced to address it directly regarding Yul Brynner's portrayal of Pharaoh Rameses in his 1956 The Ten Commandments and the accusation that it was almost the same performance as Brynner's King of Siam in the 1956 The King and I. DeMille defended the claim as follows:

I advise them [critics] to look again. Let them see The King and I and The Ten Commandments in quick succession, and they will see the subtle differences in characterization between the barbaric, puzzled, arrogantly defensive King of Siam and the no less arrogant but sophisticated, self-assured Pharaoh of The Ten Commandments. There are similarities in the two performances, for Yul Brynner, after all, is only one man; but it is the subtle differences which show his great artistic competence (DeMille and Hayne 1960, 381) [my emphasis].

Brynner's subtly graded performance under Cecil's intense coaching, to the point where Yul "became an extension of the older man's mind and behaviour" (Robbins 1987, 59), aptly demonstrated DeMille's skill of shaping actors to fit the needs of his movies.

Furthermore, not only has DeMille's deployment of subtle variation been frequently overlooked, dismissed or devalued, but the cognoscenti, literati and aesthete often accused him of the opposite aesthetic crime. For example, it was claimed that: "There were never any graduations of character in Cecil B. DeMille's world" (Bona 1996, 55) because he was "a thoroughly pedestrian director" (Preston Sturges in Jacobs 1992, 180), "a third-rate purveyor of historically distorted, paper-doll epics" (Trent 1975, 172) who made films that were 
"generally superficial and...added nothing to film art" (Wexman 2006, 83). It was also claimed that DeMille "had no particular talent. He inspired no individual performer" (Manchel 1971, 47) because he was just a "showman rather than a director" (Eyles 1967, 45). For Norman Bel Geddes:

Inspirationally and imaginatively, CB was sterile. His stories, situations and characters were, almost without exception, unintelligent, unintuitive, and psychologically adolescent. CB was a foreman in a movie factory; he fitted the parts together and demanded that they move as he thought they should. It was an early form of automation (quoted in Green 1997, 191-192).

Genre-wise, David Thomson (1995, 182) considered DeMille to be "silliest in his biblical and Roman films," Barry Norman $(1985,182)$ argued that Samson and Delilah "was certainly the worst and most absurd of all his films in that genre," whilst Giannetti and Eyman $(1996,40)$ noted that: "It is no longer fashionable to admire De Mille." These claims are mistaken and in need of urgent rejection, correction and renewal.

Despite DeMille's legendary Hollywood status and professional longevity (1913-1959), serious film scholarship has only just begun to scratch the surface of DeMille studies (Higashi 1994), and even less academic effort has been devoted to revealing all the cinematic secrets of Samson and Delilah, although this is slowly changing (Kozlovic 2002, 2003). Nevertheless, much more work is needed before Cecil's aesthetic talents can be fully revealed, acknowledged and appreciated. Consequently, the critical DeMille, film and religion literature was selectively reviewed and integrated into the text to enhance narrative coherence (albeit, with a strong reportage flavour). This was followed by a close examination of Cecil's Samson saga utilising humanist film criticism as the guiding analytical lens (i.e., examining the textual world inside the frame, but not the world outside the frame--see Bywater and Sobchack 1989). DeMille's various depictions of love within this ancient "story of sexy stories" (Wurtzel 1998, 38) were explicated herein to reveal DeMille-the-subtle-auteur in his quintessential role as a Hollywood love coach. This analysis will also help showcase why Samson and Delilah deserves to be considered one of "DeMille's grandest biblical epic" (Moses 1999, 411) and "a masterpiece of biblical film making" (Exum 2002, 255).

\section{DeMille: The Hollywood Love Coach}

The extent of DeMille's filmmaking skilfulness is even more amazing considering that Holy Writ suffers intrinsic storytelling deficiencies that need to be compensated for by narrative filmmakers. Most notably, the sacred text is "composed of events and interactions, not of feelings and inner psychological dramas. The reader must infer a great deal if she wishes to fill out the characters into complex, feeling, motivated human beings" (Merideth 1989, 70), especially concerning DeMille's famous femme fatale Delilah (Judg. 16:4-20). Whatever Delilah's "true" scriptural role, political status or emotional allegiances, "modern readers want to understand her motivations perhaps more than ancient readers did" (Bellis 1994, 126); nor did DeMillethe-dramatist disappoint his audiences in this regard. Overall, DeMille-the-Hollywood-love-coach's multiple lessons consisted of finely graduated emotional states embodied with the following eight Samson and Delilah protagonists, namely: (1) Hazel..., (2) Hisham, (3) Semadar, (4) the Harlot of Gaza, (5) Delilah, (6) Miriam, (7) Samson, and (8) the Israelite/Hebrew nation. The following is a brief explication of each them.

\section{Hazel... (Fay Holden)}

This worried Israelite/Danite/Hebrew mother of Samson (and wife of Manoah) represented non-erotic virtuous love, filial devotion and unenforceable tough love, especially concerning Samson's radical endogamy marriage plans (Judg. 14:3). DeMille had her annoyingly cry out to her husband Manoah: "What did I tell you. He wants to marry a Philistine!" Scripturally speaking, she is unnamed and repeatedly referred to as "the woman" (Judg. 13:3, 6, 9, 10,24), even by her own husband (Judg. 13:11) and God's annunciation angel (Judg. 13:13). She was an important biblical woman, fit to experience angelic revelations and chosen by God, but apparently not important enough to warrant a personal name recorded in the Book of Judges. However, DeMille labelled her "Hazeleponit" in off-screen cast lists (Ringgold and Bodeen 1969, 342) which was akin to the "Hazlelponi" of Rabbinical tradition (Reinhartz 1993, 162) and "Hazelelponi" (aka "Hazzelelponi") of 1 Chronicles 4:3 (Schwartz and Kaplan 2007, 50). During on-screen dialogue between her and Manoah, this biblical mother was orally referred to by the truncated name of "Hazel..." (a deliberate pop culture concession to the public, not poor DeMillean production values). Consequently, this name will be used herein for accuracy, comprehension and convenience reasons.

The intrinsic "goodness" (Schwartz and Kaplan 2007, 51) and associated asexuality of Samson's mother 
is consistent with her motherly on-screen characterisation by DeMille, which automatically neutered any hint of threatening sexual allure, especially contrasted to the trinity of beautiful young woman surrounding Samson, namely, DeMille's Miriam (Olive Deering), Semadar (Angela Lansbury) and Delilah (Hedy Lamarr). Although DeMille did not film the miraculous angelic events contained within Judges 13, he did extrapolate its potential sexual implications into his plump little mother characterisation in a scripturally authentic way. As biblicist J. Cheryl Exum (1993) pointed out:

...Judges 13 affirms woman in her role as mother - motherhood controlled by men; motherhood without jouissance. Our story not only denies the mother's sexual pleasure; it goes so far as to dissociate her pregnancy from the sex act, not even acknowledging in typical biblical fashion, 'Manoah knew his wife and she conceived.' Rather the story begins with the (male) messenger of Yhwh telling the woman she is pregnant. Indeed, the woman's sterility draws attention to the fact that the deity controls her reproductive ability. The absence of sex from this chapter is even more remarkable and revealing when viewed against Samson's liaisons in chs. 14-16 and against the sexual innuendoes and the pervasive sexual symbolism in these chapters... (66).

DeMille avoided any hint of sexuality concerning Hazel... because she was the quintessential "Jewish mother who whines and complains rather tediously - and not even about his [Samson's] hair!" (Samberg 2000, 62). In effect, DeMille-the-Episcopalian-Christian, whose own mother had a "Sephardic Jewish background" (Edwards 1988, 14), was deliberately perpetuating the Jewish mama stereotype that the paying public could easily identify with, and hopefully bond to in an emotionally satisfying way.

\section{Hisham (Julia Faye)}

This was an unscriptural but highly plausible secondary character associated with Delilah. DeMille designed her as a worried Philistine servant who was praised for her non-erotic services as a personal maid, and who also functioned as a mother-like confidant, girlfriend, situation commentator, comic foil, personal critic, representative of Philistines as a group, and the physical embodiment of the audience's voyeuristic impulses. Especially when she smilingly peered through tent flaps at Delilah's oasis love-nest to spy upon the lovers therein. Hisham thus demonstrated nanny-like devotion, pseudo-sexual voyeurism and the externalisation of Delilah's conscience when, for example, she warned Delilah about her Samson-stealing machinations by sagely saying: "The trouble you brew today you'll drink tomorrow." DeMille had also built character symmetry into his Old Testament (OT) film by making Hisham-the-servant-cum-intimate-personal-critic Delilah's Philistine equivalent of Samson's Jewish mother-cum-servant-cum-intimate-personal-critic. DeMille made sure that both Samson and Delilah were under evaluative scrutiny by close peers to underscore the film's moral dimensions and to give the audience access to intimate feelings and inner psychological states which are traditionally denied one by only reading Holy Writ.

\section{Semadar (Angela Lansbury)}

This biblically unnamed Philistine woman of Timnath (Judg. 14:1) was called Semadar by DeMille. She represented the excited anticipatory love of a new wife-to-be and thus of erotic physical attraction in the authentic biblical tradition of Samson saying "she pleaseth me well" (Judg. 14:3), which DeMille dialogically rendered as "Semadar pleases me." Samson had expected to go from social intercourse to sexual intercourse when Semadar became the object of his urgent sexual desire. Not surprisingly, Caroline Pressler (2002, 208) considered the scriptural Samson to be a "brawny, bawdy, amoral adventurer" whilst her biblicist peer Claudia Camp $(2000,131)$ considered him to be "a lusty bully who gets what he deserves from the manipulative 'love' of his foreign women." For the physically blind John Hull $(2001,10)$, this OT love match was superficial from the very start because it was "based only on visual beauty." Tammi Schneider (2000, 214) even suggested that "if Samson and the woman [DeMille's Semadar] were officially married [then] the Philistine father [DeMille's Tubal (William Farnum)] turned his daughter into an adulteress." How? Because he took her away from Samson and gave her to Samson's biblically unnamed "companion" (Judg. 14:20; 15:2,6) whom DeMille made a major protagonist-rival and called Ahtur (Henry Wilcoxon).

This reading may help explain why the Philistines, who were very annoyed at the arsonist behaviour of Samson-the-Israelite (Judg. 15:4-5), "our enemy, and the destroyer of our country" (Judg. 16:24), subsequently burnt to death the Timnath woman (DeMille's Semadar) and her Philistine father (DeMille's Tubal) instead of going after the guilty perpetrator, Samson (Judg. 15:6). And especially considering that this 
Danite judge was textually described as "Samson, the son in law of the Timnite" (Judg. 15:6) whom had considered that his Timnite father-in-law "had taken his wife, and given her to his companion" (Judg. 15:6). In which case, Semadar is indicative of adulterous love and flexible allegiances whether political, social, emotional, ethnic or religious. Indeed, DeMille had dramatically aggravated Tubal's adultery-generating crime by having him personally marry Semadar to Samson in his own home. Tubal then personally organised the giving away of Semadar to Ahtur after he thought Samson had rejected her; along with a little bit of malicious nudging by Delilah, Semadar's sister and love triangle rival according to DeMille-the-creative-imaginer.

After DeMille's spearing death of Semadar, her body was presumably consumed in the house fire along with her father according to Scripture (Judg. 15:6), although DeMille never actually showed any grisly charred bodies or graphic immolation scenes. Instead, he had his Samson depart Tubal's house prematurely, leaving behind a raging spot fire, a dead Semadar pinned to a wall with a Philistine spear, some stunned wedding guests, and a very troubled Tubal. Later, DeMille depicted Tubal's house burning furiously in the far distance as both Delilah and Hisham contemplated their uncertain futures following their micro-Holocaust experience. Tubal had thus suffered a cinematic death as sure as his scriptural death. Later on, DeMille's Delilah briefly referred to Tubal's death to justify her rage against Samson before the Saran of Gaza (George Sanders) and his fuming Philistine cohorts.

\section{The Harlot of Gaza (unseen)}

Biblically speaking, Samson's womanising behaviour was confirmed during his one-night-stand with an unnamed prostitute in Gaza when he "saw there a harlot, and went in unto her" (Judg. 16:1), presumably to compensate for his lost wedding night delights after the unexpected loss-cum-death of his Timnite wifeto-be (Judg. 15:6). Although no money changing hands was recorded, it is traditionally assumed that this encounter was a loveless, lust-filled commercial transaction as suggested by the word "harlot." This biblical harlot thus represented detached sexual relief, casual sexual gratification and possibly enhanced sexual excitation for Samson. Why? Because as John Hull $(2001,12)$ suggested, there "must be something terribly exciting about engaging in such behaviour right under the noses, so to speak, of his enemies," and especially while Samson was "on the Philistines' most-wanted list" (Harris, Brown and Moore 2000, 254).

Although DeMille did not film this erotic scriptural episode (nor did Lee Philips in his 1984 Samson and Delilah, although Nicolas Roeg did so in his 1996 Samson and Delilah), during script conferences he mentally conceived of his Samson as a "whoremonger" (Koury 1959, 218). DeMille also gave a dialogue hint of Samson's profligate ways at the beginning of his film when a defensive young Saul (Russell Tamblyn) championed him and in response a Philistine soldier incredulously cried out: "Samson!!...He saves his strength for the wenches!" DeMille's reference to "wenches" was apt for this is an archaic name for "a prostitute" or "to frequent the company of prostitutes" for promiscuous sex (Hanks et al. 1982, 1646). In effect, DeMille-the-artist was being very subtle about Samson's sexual indiscretions in the very act of loudly pointing them out to the audience.

\section{Delilah (Hedy Lamarr)}

This famous femme fatale represented the passions of a controlling manipulative lover and thus indicative of obsessive physical lust. As DeMille's girlish-Delilah desperately cried out to Samson at his wedding feast: "You're the only thing in the world I want!" and then later at the oasis love-nest trap, the mature-Delilah jealously told Miriam: "I love him as a man of flesh and blood!" Delilah also illustrated the horrendous dangers of unreciprocated love coupled with her flexible emotions and shifting political allegiances as she embarked upon a cunning plan to ensnare Samson and become the "mistress of the secret" (Thomas 1994, 222), that is, the non-family repository of Samson's strength secret (i.e., uncut hair). DeMille's Delilah also represented possessive love for as she warned Samson at the oasis love-nest: "I'm the weakness, the love that would enslave you." As Joel Samberg (2000, 62) humorously noted: "Of course, Victor Mature [Samson] eventually does take up with Hedy Lamarr [Delilah], who chops off his hair, rendering him weak and helpless. Before long he is blinded, tortured, and killed. Now there's one Jewish boy who should have listened to his mother!"

Biblicist Lillian Klein (1993, 62-63) considered that Delilah was "the worst of the three 'lovers' in Samson's narrative... [and that to] the Israelite reader, Delilah is depicted as worse than a prostitute, a claim supported by her appearance as the female climax in Judges' cyclical sequence of flawed characters." After all, the 
Book of Judges is an ancient condemnatory treatise demonstrating "that it was a shameful period in Israel's history; that Israel was in religious and political decline; [and] that Israel's judges had feet of clay" (Dorsey 1999, 120). This claim was dramatically exemplified by the clay-strength morality of Samson, the last of the judges (i.e., charismatic leaders) who was easily distracted by sex imperatives and then eventually toppled by an extremely persistent Delilah. Unlike Samson's loving mother, Delilah is "pushy and demanding, exploiting his love for her...She manipulates and harasses Samson to his downfall, and she even torments him once he has been weakened" (Schwartz and Kaplan 2007, 52). Indeed, she symbolically castrated him by having his hair shorn (Judg. 16:19) to further un-man this strongest man in the world.

DeMille-the-artist was never as crass or crude to call his Delilah a "prostitute," a "whore," a "harlot," a "slut," a "nympho" etc., but he did have Samson emotionally call her a "courtesan" whilst raiding her oasis tent. The word "courtesan" was just another nice name for "a prostitute, or the mistress of a man of rank" (Hanks et al. 1982, 344). Samson's verbal tag of "courtesan" definitely had an upper class resonance that matched Delilah's regal role as the intimate companion of the Philistine leader, the Saran of Gaza, and then later as the companion of Samson himself, the Danite leader and chosen of God (Judg. 13:3, 24-25) who frequented harlots (Judg. 16:1). Indeed, the opulent trappings of Delilah's oasis love-nest were the ancient world equivalent of an up-market Western bordello, and just as exotic and out-of-place as in any other frontier zone frequented by lusty rustics looking for a rutting good time.

Whatever Delilah's other faults, DeMille certainly captured her biblical reputation as "the gauge of evil - foreigner, seductress, betrayer" (Klein 1993, 67) as well as her status as "Samson's famous paramour" (Weitzman 2002, 161), and "Samson's lover-betrayer" (Pressler 2002, 222). As novelist Fay Weldon (1995, 80) cheekily imagined Delilah saying about her own harlotry: "You live to find out that the thing most likely to put a man off his stroke is his mother, and that's always worth knowing!" Indeed, this is exactly what happened to DeMille's Samson. The virtuous Miriam rushed to Delilah's oasis love-nest to summons Samson because his mother was chained and whipped by the Philistines, and in her deep despair she cried out for her son. Samson's filial devotion towards his mother quickly shifted his erotic allegiances away from Delilah whom he quickly stopped romancing and delayed their plans to run away to Egypt together; a delay the miffed Delilah and prompted her subsequent betrayal that was made permanent and world famous thereafter.

Later, DeMille's Delilah suffered emotional guilt over her treachery and then she became the embodiment of restorative love that would willingly endure Samson's hatred to put things right. At film's end, when Delilah ignored the blind Samson's loving advice to leave the arena, she died in Dagon's toppled temple along with the rest of the taunting Philistines. Delilah thus exemplified unheeded love, but this time because of her positively skewed obsessive-cum-redemptive love that ironically had succeeded in blinding her to common sense (itself the stereotypic romantic hallmark of "true" love).

\section{Miriam (Olive Deering)}

This young, plain Jane, Israelite/Danite/Hebrew woman represented heartfelt unrequited love, unreciprocated love, patient love, longing love, passive but hopeful love for when she painfully said to Samson after he had overlooked her as his potential wife: "I'll always be here." She is a very plausible if unscriptural "good girl" fiction whom DeMille modelled upon the "Virgin Mary" (Koury 1959, 231) to dramatically counter-balance Delilah the "bad girl" in this binary fashion (and itself another of his auteur trademarks). DeMille's Samson called her an "angel" and confessed: "Miriam...you're further above me than the moon" so as to emphasise her heavenly quality. Even DeMille's Delilah (and Philistine romantic rival) called Miriam "a milk-faced girl with a cow's eyes" and a "milk-faced Danite lily" at the oasis love-nest, thereby reinforcing Miriam's pretty, girlish, virginal qualities. Delilah even admitted to Samson: "You belong to Miriam, she's the good in you," thus Miriam also represented spiritual, holy love that even romantic rivals/ethnic enemies could see. On an erotic scale of things, DeMille's fictional Miriam sits inbetwixed Samson's plump, sexually unavailable mother, and Delilah, the eminently available seductive sorceress of Sorek. Since Miriam is the only character in Samson and Delilah not to have any romance, sex or even a hint of an active love life, this says something very disturbing about the fate of good girls everywhere.

\section{Samson (Victor Mature)}

Unlike Samson's previous female relationships, DeMille had him fall into deep romantic love with Delilah, as indicated when Samson truthfully said to her at the oasis love-nest: "My eyes...could never find more beauty 
than they see in you." This is a common and not unreasonable interpretation of Scripture, however, Betsy Merideth $(1989,77)$ suggested that the scriptural Samson was not in romantic love, but merely fulfilling his lust drive because the biblical phrase: "he loved a woman in the valley of Sorek" (Judg. 16:4) was merely "a statement of fact and location, that is, that he was sleeping with a woman in the valley of Sorek." Therefore, this love claim was not real romantic love, but lust geographically documented, just like the Scriptures had geographically documented Samson's two other lovers, the Philistine woman in "Timnath" (Judg. 14:1) and the harlot in "Gaza" (Judg. 16:1).

In DeMille's defence, the romantic interpretation regarding Delilah is more plausible given that the Scriptures say that Samson "loved" (Judg. 16:4) a woman in the valley of Sorek whereas he only "saw" (Judg. 14:1) a woman in Timnath (DeMille's Semadar), and he only "saw" (Judg. 16:1) the Gaza harlot (unfilmed but indirectly referenced by DeMille). Indeed, the scriptural use of the identical word "saw" to describe both the Gaza harlot and his fickle Timnath wife-to-be indirectly suggests that Samson's unfaithful Timnath spouse is the equivalent of a harlot for her adulterous marriage to Samson's companion (Judg. 14:20; 15:2, 6), DeMille's Ahtur, and thus supportive of Tammi Schneider's $(2000,214)$ adultery claim. Samson was also the victim of controlling love through negative emotions such as manipulative weeping by the Timnath woman (Judg. 14:16-17) and persistent strategic nagging by Delilah (Judg. 16:16), which DeMille also cinematically rendered accurately on-screen. This was also coupled with Samson's inability to manage relationships through bedding and wedding which, theologically speaking, was "Samson's Achilles' heel" (Harris, Brown and Moore 2000, 243). Samson's death was the end of the reign of the judges as well as Samson's hereditary line, although it is possible that his liaisons with harlots may have produced some offspring, albeit, not scripturally documented.

Not only was Samson a victim, but he was a repeat victim of betraying manipulative love, especially "when Delilah saw that he had told her all his heart, [and then] she sent and called for the lords of the Philistines" (Judg. 16:18). DeMille had his Samson betrayed on multiple occasions, but in the Jesus tradition of forgiving, coupled with DeMille's subtextual construction of Samson as a Christ-figure (Kozlovic, 2003), his Samson forgave Delilah her treachery whilst in the Gaza prison mill, thus indicating redemptive love and conciliatory love. Samson also demonstrated protective love towards her when he did not kill her when he had the chance in the prison mill, and then again when he asked Delilah not to stay in Dagon's temple, which he was about to bring crashing down. However, the lovelorn Delilah ignored him and subsequently died along with her Philistine kinsmen and Samson himself (itself another stereotypic romantic hallmark of "true" love). Previously, Samson provided this same protective love packaged as advice to young Saul and through him to Miriam, both of whom survived the devastating temple toppling because of Samson's apt warning (and itself a subtle indicator of a man-of-God on a holy kamikaze mission to punish evil-doers; not blameless kinsmen).

\section{The Israelite/Hebrew Nation}

Religiously speaking, the Israelites/Hebrews had a love affair with their judges as indicated by a whole section of the Bible devoted to their exploits, namely, the Book of Judges (1:1-21:25). DeMille's Lesh Lakish (John Miljan) firmly stated this fact while in the house of Miriam's grandfather to underscore this relationship and help establish DeMille's legitimate biblical credentials. However, this political love of religion, this national love, this ethnic love was in essence a declining love as the various exploits of the judges intimately mapped Israel's religio-political decline into apostasy. This cancerous moral decay ultimately lead to the immoral escapades of Samson, the ancient "wonder-man" (Harris, Brown and Moore 2000, 243) and the last of the judges of premonarchical Israel.

Although "Samson was the strongest man on earth. The World Wrestling Federation had nothing on him" (Bolton 1998, 93), he was still the weakest of God's judges despite his devastating physical successes against the Philistines. Why? Because "for the first time Israel's deliverer will not deliver them completely" (Harris, Brown and Moore 2000, 240), and of all the judges "only Samson fails to restore the tribes' independence" (Pressler 2002, 209). However, this "failure" was also biblically foreshadowed by God's annunciation angel who said to Samson's mother that her son "shall begin to deliver Israel out of the hands of the Philistines" (Judg. 13:5) [my emphasis]. Samson had achieved a small victory for God as cosmically mandated, but ironically, this holy deed was not up to par compared to the exploits of the rest of the judges who did not have Samson's phenomenal physical advantages. 


\section{Conclusion}

These subtle and wide-ranging varieties of engineered love within Samson and Delilah grew out of authentic biblical character traits and legitimate readings of the Bible, which DeMille sought to filmicly emulate in his own midraschic, countercoherence, and hermeneutic of creative imagination fashion. They also clearly demonstrate that DeMille had gone to great pains to ensure emotional authenticity, thereby belying the claim that: "There were never any graduations of character in Cecil B. DeMille's world" (Bona 1996, 55). Cecil was certainly a more accomplished, sensitive and subtle filmmaker than has been critically acknowledged to date, whilst simultaneously making it entertaining for the public, profitable for Paramount and pleasing for the religion profession. At least DeMille's superiors knew his true worth for as movie mogul David O. Selznick confessed to fellow mogul Louis B. Mayer:

However much I may dislike some of his [DeMille's] pictures from an audience standpoint, it would be very silly of me, as a producer of commercial motion pictures, to demean for an instant his unparalleled skill as a maker of mass entertainment, or the knowing and sure hand with which he manufactures his successful assaults upon a world audience that is increasingly indifferent if not immune to the work of his inferiors. As both professionally and personally he has in many ways demonstrated himself to be a man of sensitivity and taste, it is impossible to believe that the blatancy of his style is due to anything but a most artful and deliberate and knowing technique of appeal to the common denominator of public taste. He must be saluted by any but hypocritical or envious members of the picture business. But there has appeared only one Cecil B. DeMille (Behlmer 1972, 400).

One can only agree with him. However, a closer, more sympathetic examination of DeMille's entire filmic oeuvre (52 silent, 18 sound) will wield many more insights and delights unappreciated to date. Further research into DeMille studies, biblical epics and the emerging interdisciplinary field of religion-and-film (aka sacred cinema, spiritual cinema, holy film, cinematic theology, cinematheology, theo-film, celluloid religion, film-and-faith, film-faith dialogue) is warranted, recommended and certainly long over due, whether as film studies, religion studies, cultural studies or communication studies.

\section{Notes}

1. There is not one DeMille persona but many DeMille personas. His career was so long, complex and multifaceted that to describe, let alone justify each aspect would be prohibitive. Therefore, concise hyphenated compound terms will be used throughout to help disentangle his various roles and avoid needless repetition, redundancy or reader boredom.

2. Many scholars have spelled Cecil's surname as "De Mille" or "de Mille" or "deMille" however, the correct professional spelling is "DeMille" (DeMille and Hayne 1960,6), and so it will be spelled herein, along with its concomitants "Cecil" and "CB" as appropriate.

3. (Birchard 2004; DeMille and Hayne 1960; Edwards 1988; Essoe and Lee 1970; Higashi 1985, 1994; Higham 1973; Koury 1959; Louvish 2008; Noerdlinger 1956; Orrison 1999; Ringgold and Bodeen 1969).

4. The Authorized King James Version of the Bible (KJV aka AV) will be used throughout because it was frequently used by DeMille (Higashi 1994, 180). Furthermore, most of the biblical phrases that are embedded in our culture are from the King James Version, which is still the most widely used English translation today (Taylor 1992, ix, 71).

\section{References}

Behlmer, R., ed. 1972. Memo from David O. Selznick. New York: The Viking Press.

Bellis, A.O. 1994. Helpmates, harlots, and heroes: Women's stories in the Hebrew Bible. Louisville, KY: Westminster/John Knox Press.

Birchard, R. S. 2004. Cecil B. DeMille's Hollywood. Lexington: University Press of Kentucky. 
Bolton, M. 1998. Never ask Delilah for a trim... and other good advice. Ann Arbor, MI: Servant Publications. Bona, D. 1996. Starring John Wayne as Genghis Khan. Secaucus, NJ: Citadel Press.

Brode, D. 1995. The films of Steven Spielberg. New York, NY: Citadel Press.

Bywater, T., and T. Sobchack. 1989. An introduction to film criticism: Major critical approaches to narrative film. New York: Longman.

Camp, C. V. 2000. Wise, strange and holy: The strange woman and the making of the Bible. Sheffield: Sheffield Academic Press.

Clapham, W.C. 1974. The movie treasury. Western movies: The story of the West on screen. London: Octopus Books.

DeMille, C. B., and D. Hayne, ed. 1960. The autobiography of Cecil B. DeMille. London: W. H. Allen.

Dorsey, D. A. 1999. The literary structure of the Old Testament: A commentary on Genesis-Malachi. Grand Rapids, MI: Baker Books.

Edwards, A. 1988. The DeMilles: An American family. London: Collins.

Essoe, G., and R. Lee. 1970. DeMille: The man and his pictures. New York: Castle Books.

Exum, J. C. 1993. Fragmented women: Feminist (sub)versions of biblical narratives. Sheffield: Sheffield Academic Press.

, 1996. Plotted, shot, and painted: Cultural representations of biblical women. Sheffield: Sheffield Academic Press.

, 2002. Lethal woman 2: Reflections on Delilah and her incarnation as Liz Hurley. In Borders, boundaries and the Bible, ed. M. O'Kane, 254-273. London: Sheffield Academic Press.

Eyles, A. 1967. The western: An illustrated guide. New York: A. S. Barnes.

Finler, J. W. 1985. The movie directors story. London: Octopus Books.

Fiorenza, E. S. 2001. Wisdom ways: Introducing feminist biblical interpretation. Maryknoll, NY: Orbis Books.

Giannetti, L., and S. Eyman. Flashback: A brief history of film. 3rd ed. Englewood Cliffs, NJ: Prentice-Hall. Green, J. 1997. Dictionary of insulting quotations. London: Cassell.

Gussow, M. 1971. Darryl F. Zanuck: Don't say yes until I finish talking. New York, NY: Da Capo.

Hanks, P., T.H. Long, L. Urdang, and G.A. Wilkes, eds. 1982. Collins dictionary of the English language. Sydney: Collins.

Harris, J. G., C. A Brown, and M. S. Moore. 2000. New international biblical commentary: Joshua, Judges, Ruth. Peabody, MA: Hendrickson.

Higashi, S. 1985. Cecil B. DeMille: A guide to references and resources. Boston, MA: G.K. Hall \& Co. 1994. Cecil B. DeMille and American culture: The silent era. Berkeley: University of California Press.

Higham, C. 1973. Cecil B. DeMille. New York: Charles Scribner's Sons.

Holloway, R. 1977. Beyond the image: Approaches to the religious dimension in the cinema. Geneva: World Council of Churches.

Hull, J. M. 2001. In the beginning there was darkness: A blind person's conversations with the Bible. London: SCM Press.

Jacobs, D. 1992. Christmas in July: The life and art of Preston Sturges. Berkeley: University of California Press. 
Jasper, D. 1999. Literary readings of the Bible: Trends in modern criticism. In The Bible and literature: A Reader, eds. D. Jasper, S. Prickett, and A. Hass, 44-64. Oxford: Blackwell.

Klein, L. R. 1993. The Book of Judges: Paradigm and deviation in images of women. In A feminist companion to Judges, ed. A. Brenner, 55-71. Sheffield: Sheffield Academic Press.

Koury, P.A. 1959. Yes, Mr. De Mille. New York: Putnam.

Kozlovic, A.K. 2002. The whore of Babylon, suggestibility, and the art of sexless sex in Cecil B. DeMille's Samson and Delilah (1949). In Sex, religion, media, ed. D.S. Claussen, 21-31. Lanham, MD: Rowman \& Littlefield.

2003. Have lamb will martyr: Samson as a rustic Christ-figure in Cecil B. DeMille's Samson and Delilah (1949). Reconstruction: Studies in Contemporary Culture 3 (1): 1-23. [http://www.reconstruction.ws/031/kozlovic.ht

Long, R. E., ed. 2001. George Cukor interviews. Jackson: University Press of Mississippi.

Louvish, S. 2008. Cecil B. DeMille: A life in art. New York: Thomas Dunne Books/St. Martin's Press.

Manchel, F. 1971. When pictures began to move. Englewood Cliffs, NJ: Prentice-Hall.

Merideth, B. 1989. Desire and danger: The drama of betrayal in Judges and Judith. In Anti-covenant: Counter-reading women's lives in the Hebrew Bible, ed. M. Bal, 63-78. Decatur, GA: The Almond Press.

Moses, R., ed. 1999. American Movie Classics classic movie companion. New York: Hyperion.

Murphy, C. 1999. The word according to Eve: Women and the Bible in ancient times and our own. London: Allen Lane/The Penguin Press.

Noerdlinger, H. S. 1956. Moses and Egypt: The documentation to the motion picture The Ten Commandments. Los Angeles: University of Southern California Press.

Norman, B. 1985. The film greats. London: Hodder and Stoughton/British Broadcasting Corporation.

Orrison, K. 1999. Written in stone: Making Cecil B. DeMille's epic, The Ten Commandments. Lanham: Vestal Press.

Paglia, C. 1994. Vamps \& tramps: New essays. New York: Vintage Books.

Pressler, C. 2002. Joshua, Judges, and Ruth. Louisville: Westminster John Knox Press.

Reinhartz, A. 1993. Samson's mother: An unnamed protagonist. In A feminist companion to Judges, ed. A. Brenner, 157-170. Sheffield: Sheffield Academic Press.

Ringgold, G., and D. Bodeen. 1969. The complete films of Cecil B. DeMille. Secaucus, NJ: The Citadel Press.

Robbins, J. 1987. Yul Brynner: The inscrutable king. New York: Dodd, Mead \& Company.

Samberg, J. 2000. Jewish moms in the movies. Moment 25 (5): 62.

Schatz, T. 1997. History of the American cinema. 6. Boom and bust: The American cinema in the 1940s. New York: Simon and Schuster Macmillan.

Schneider, T. J. 2000. Judges. Collegeville, MN: The Liturgical Press.

Schwartz, M. B., and K. J. Kaplan. 2007. The fruits of her hands: A psychology of biblical women. Grand Rapids, MI: William B. Eerdmans.

Taylor, M. D. 1992. The complete book of Bible literacy. Wheaton, IL: Tyndale.

Thomas, A. 1994. An illustrated dictionary of narrative painting. London: John Murray \& National Gallery Publications.

Thomson, D. 1995. A biographical dictionary of film. $3^{\text {rd }}$ ed. New York: Alfred A. Knopf.

Trent, P. 1975. Those fabulous movie years: The 30s. Barre, MA: Barre Publishing. 
Vidal, G. 1995. Palimpsest: A memoir. London: Andre Deutsch.

Weitzman, S. 2002. The Samson story as border fiction. Biblical Interpretation: A Journal of Contemporary Approaches 10 (2): 158-174.

Weldon, F. 1995. Samson and his women. In Out of the garden: Women writers on the Bible, eds. C. Buchmann and C. Spiegel, 72-81. New York: Fawcett Columbine.

Wexman, V. W. 2006. A history of film. $6^{\text {th }}$ ed. Boston: Pearson/A and B.

Wurtzel, E. 1998. Bitch: In praise of difficult women. New York: Doubleday.

\section{Filmography}

The King and I (1956, dir. Walter Lang)

The King of Kings (1927, dir. Cecil B. DeMille)

Samson and Delilah (1949, dir. Cecil B. DeMille)

Samson and Delilah (1984, dir. Lee Philips)

Samson and Delilah (1996, dir. Nicolas Roeg)

The Ten Commandments (1923, dir. Cecil B. DeMille)

The Ten Commandments (1956, dir. Cecil B. DeMille)

\section{Author Information}

Anton Karl KOZLOVIC (PhD Flinders) researches in the Screen Studies department, School of Humanities at Flinders University (Adelaide, Australia). His interests include religion-and-film, computer films, and the biblical cinema of Cecil B. DeMille. He has published in journals including Australian Religion Studies Review, Belphegor: Popular Literature and Media Culture, The Film Journal, Journal of Contemporary Religion, The Journal of Religion and Film. 